\title{
NURSES' TRAINING IN PREHOSPITAL CARE ${ }^{1}$
}

Rosana Chami Gentil ${ }^{2}$

Laís Helena Ramos ${ }^{3}$

Iveth Yamaguchi Whitaker ${ }^{4}$

Gentil RC, Ramos LH, Whitaker IY. Nurses' training in prehospital care. Rev Latino-am Enfermagem 2008 março-abril; 16(2):192-7.

The performance of nurses in prehospital care (PHC) assumes acquiring specific competences. The objectives of the present study were to verify nurses' opinion on theoretical knowledge and nursing skills necessary for the practice in pre-hospital setting and to analyze them according to their clinical practice. In this descriptive study, the opinion of nurses, from public pre-hospital care services of the City of São Paulo, was collected through a questionnaire and the data of the clinical practice using forms. Cardiopulmonary resuscitation was mentioned more often as basic knowledge (84\%), and the most frequent procedure was oxygen therapy (15.5\%). The analysis of nurses' opinion indicated that the basic topics were related to situations that demanded making decisions, readiness and skill under stress or caring for a specific population, making training important in this area.

DESCRIPTORS: emergency nursing; education; emergency medical services; human resources formation

\section{LA CAPACITACIÓN DE ENFERMEROS PARA LA ATENCIÓN PRE-HOSPITALARIA}

La actuación del enfermero en el área de atención pre-hospitalaria (APH) presupone la adquisición de competencias específicas. Los objetivos de este estudio fueron verificar la opinión de los enfermeros sobre conocimientos teóricos y habilidades de enfermería necesarias para el ejercicio en la APH y analizarlas conforme su práctica clínica. En este estudio descriptivo, la opinión de los enfermeros de los servicios públicos de la APH del Municipio de San Pablo fue recolectada por medio de un cuestionario y los datos de la práctica clínica en un formulario. La resucitación cardiopulmonar fue más citada como conocimiento básico (84\%) y el procedimiento más frecuente fue la oxigenoterapia (15,5\%). El análisis de las opiniones de los enfermeros reveló que los temas considerados básicos estaban relacionados a las situaciones que exigen una toma de decisión, rapidez y destreza bajo estrés o atención de una población específica, lo que refuerza la importancia de la capacitación en esa área.

DESCRIPTORES: enfermería en emergencia; educación; servicios médicos de emergencia; formación de recursos humanos

\section{CAPACITAÇÃO DE ENFERMEIROS EM ATENDIMENTO PRÉ-HOSPITALAR}

A atuação do enfermeiro na área de atendimento pré-hospitalar ( $A P H$ ) pressupõe a aquisição de competências específicas. Os objetivos deste estudo foram verificar a opinião dos enfermeiros sobre conhecimentos teóricos e habilidades de enfermagem necessários para o exercício em APH e analisá-la de acordo com a prática clínica. Neste estudo descritivo, a opinião dos enfermeiros dos serviços públicos de APH do Município de São Paulo foi coletada por meio de questionário, e os dados da prática clínica em formulário. A ressuscitação cardiopulmonar foi mais citada como conhecimento básico (84\%) e o procedimento mais freqüente foi a oxigenoterapia (15,5\%). A análise das opiniões dos enfermeiros revelou que os temas considerados básicos relacionaram-se às situações que exigem tomada de decisão, prontidão e destreza sob estresse, ou atendimento de uma população específica, o que reforça a importância da capacitação nessa área.

DESCRITORES: enfermagem em emergência; educação; serviços médicos de emergência; formação de recursos humanos

${ }^{1}$ Article extracted from Master's Thesis; ${ }^{2}$ RN, M.Sc. in Nursing, e-mail: enfair@uol.com.br; ${ }^{3}$ PhD in Nursing, Adjunct Professor; ${ }^{4}$ PhD in Nursing, Adjunct Professor. Sao Paulo Federal University, Brazil 


\section{INTRODUCTION}

The efficiency of early care for people in emergency situation, either due to sudden illness, accidents or violence, led to the development of several public and private health services of prehospital care (PHC), and interhospital transfer.

The development of these services ends up with the need for skilled professionals that meet the specificities of nursing care, during PHC or interhospital transfer, aiming at health prevention, protection, and recovery.

Among the important competences for the practice of PHC are nursing clinical thinking for decision making, and skills to perform interventions promptly.

In the United States of America, background, experience and skills demanded from nurses to work at PHC vary among the States, and the courses are usually extensive with a broad content. Obtaining the license to work at PHC includes experience of, at least, 1 to 3 years in care of emergency services or critical patients, including certification in specific courses to develop skills ${ }^{(1)}$.

In France, the system of emergency care, Services d'Aide Medicále Urgente, is made up by nurses experts in anesthesiology. French nurses start nursing undergraduation in intensive care units and in practices of advanced life support to acquire competence for emergency care ${ }^{(2)}$.

In Brazil, specialization courses in emergency or PHC are still recent. Different from American and French nurses, Brazilian nurses are qualifying in this area, through specialization courses (lato sensu) in emergency or PHC, following the guidelines of the Ministry of Education and the Federal Nursing Council $^{(3)}$.

Currently, emergency care in the city of São Paulo is performed by the PHC Service of the Municipal Health Secretariat together with the Secretariat of Public Safety of the State ${ }^{(4)}$. In these services, care to severe patients and those in need for invasive procedures is performed by doctors and nurses in advanced support units.

Standardization of the structure and operation of PHC services in Brazil took place only in 2002, over one decade after its introduction, through the regulation \# 2,048 of the Ministry of Health, and this is the first regulation proposed with issues, contents, skills and minimal work load regarding specific training for nurses in $\mathrm{PHC}^{(5)}$. The regulation of the Ministry of
Health also proposes the existence of Emergency Education Centers, "that must be organized in spaces of inter-institutional knowledge for education, training and continuous development skills of human resources for emergency".

Considering that, in Brazil, PHC is an emerging area for the work of nurses, programs or training courses to meet the demands of specific, qualified education adjusted to Brazilian standards are still lacking. Thus, this study aims at identifying the opinion of nurses on theoretical knowledge and skills needed for PHC and assess them according to clinical practice experienced by nurses in public PHC services. Thus, the present study intends to offer contributions to build and plan PHC education and training programs for nurses.

\section{METHODOLOGY}

Descriptive, exploratory, study with a population of nurses from public services working in pre-hospital care in the city of São Paulo, Serviço de Atendimento Móvel de Urgência - Ambulância de Suporte Avançado (Mobile Emergency Care Service - Advanced Care Ambulance) - (SAMU 192- ASA) and Serviço de Atendimento Médico de Urgência - Unidade de Suporte Avançado (Mobile Emergency Care Service- Advanced Life Support Unit) (SAMU 193 USA), that agreed to take part in the study.

PHC's charts available, filled in by nurses of ASA-192 and USA -193, from January to December 2004 were another source of data.

The project started after the project was approved by the Ethical Research Committee of the Federal University of São Paulo/ Paulista School of Medicine - UNIFESP / EPM and, data collection was authorized in prehospital care services of the city of São Paulo - SAMU 192/193.

Two data collection instruments have been used. Nurses received a questionnaire with closed and open questions regarding sociodemographic data (age, gender, and professional background), professional experience, knowledge and skills.

Questions on PHC knowledge and skills were based on the provisions of Regulation \# 2,048 ${ }^{(5)}$. Each item of the Regulation was classified as: basic and complementary to assess if these theoretical contents and skills were part of nurses working at PHC. The option "I don't know" was also presented as an answer 
possibility. In addition to the items of the regulation, some questions have been included so that nurses could indicate other theoretical content and skills (basic or complementary) that were necessary for PHC practice.

Basic was understood as those skills that were basic, main, essential, and complementary were all other skills complementing elementary.

To obtain data from $\mathrm{PH}$ charts, whose records have been made by nurses of SAMU 192/193, another instrument has been designed. Data from the charts were: patients' age and gender; type of event (clinical or trauma) types of injury; performed procedures; clinical follow-up, and type of transportation used.

Data collection started by handing out questionnaires which were left in a closed envelope in the workplace. Obtaining answers from nurses was difficult and took 5 months.

Nurses that agreed to take part in the research gave their written consent, following the provisions of Regulation 196/96 of the National Health Council/ Ministry of Health, Art.25.

Procedure of data collection from PHC charts at SAMU 192/193 was performed based on a random sample of 15 days each month. Days from each month were randomly chosen and then from this, through a raffle of the week day 15 alternated days have been selected. After data have been selected, charts of each day were chronologically ordered and, through random choice, a chart was withdrawn and data have been collected.

Data obtained from questionnaires on knowledge and skills "basic and complementary" were manually tabulated, repeated answers have not been counted. Demographic data of nurses, those referring to closed questions and data of PHC charts have been organized in electronic spreadsheets (Microsoft Excel ${ }^{\circledR}$ ) and verify in absolute numbers and percentages.

\section{RESULTS AND DISCUSSION}

Of the total questionnaires given (101), 25 $(24.7 \%)$ were returned. Among nurses that answered the questionnaire, most (76.0\%) were females, with ages ranging from 40 to 44 (37.5\%), that had graduated between 17 to 21 years ago (37.5\%). Eighty-four percent of nurses had specialization; $20 \%$ had a Master degree, and $8.0 \%$ a Doctorate degree. Among them, $84.0 \%$ were experienced in adult emergency care, and $60.0 \%$ were experienced in adult intensive care; most of them had been working at SAMU 193 (54.5\%) and SAMU $192(61.1 \%)$ for 1 to 5 years, and had more than one job.

All nurses (25) classified as basic or complementary the theoretical content and skills needed for clinical practice at PHC, based on Regulation \# 2,048 of the Ministry of Health.

Of the total of 23 items relating with theoretical content and skills proposed by Regulation 2,048, 21 were considered as basic for suitable capacity building of PHC professionals (over 64\%).

Basic life support and management of equipment necessary to circulatory emergency care were pointed out as basic by $84 \%$ of nurses.

Other issues considered as basic by $80.0 \%$ of nurses referred to: actions to control severe respiratory distress, including those for basic life support and managing basic and advanced ventilation equipment; signs of respiratory dysfunction prevalent in children; trauma emergencies in adult patients, pregnant women, elderly and in children; signs of severity of trauma victims; respiratory and circulatory distress; initial care and maneuver techniques of severe trauma patients; care of pregnant women in normal labor, dystocia, and obstetric complications.

Issues related to actions to control and treat initial picture of exogenous intoxication and knowledge and psychomotor skills to perform land, sea, and air rescue have not been considered as basic but rather complementary by $52.0 \%$ and $76.0 \%$ of nurses, respectively.

When asked about other theoretical knowledge that they considered as basic for PHC practice, in addition to those defined by Regulation 2,048, 21 nurses (84\%) mentioned as follows.

Theoretical basic content most commonly indicated by nurses (five) was "physical pathological alterations and clinical emergencies".

Despite the low frequency, several other basic theoretical contents have been pointed out by nurses: emergency medication, drugs and behavior in prehospital care, prevention of accidents, signing and care with safety, legislation (limit for professional action in case of children, elderly or women abuse), wounds caused by venomous animals and performance of professionals on the prehospital care ambulance. 
It is important to highlight that, apart from issues of legislation and wounds caused by venomous animals, the remaining items are provided in the content of Regulation 2,048, they are parts or subitems of the issues.

On the other hand, as complementary theoretical content, suggested by nurses, in addition to those defined by the Regulation, those most commonly mentioned were: training for identifying signs of acute heart diseases on ECG (reading and interpreting); individual safety and safety of the team, care to multiple victims; use of individual protection equipment (EPI), use of criteria to assess severity of victims - use of trauma scales/indexes (Glasgow Coma Scale and Revised Trauma Score) and management of services and $\mathrm{PHC}$.

Due to their relevance, the following issues should be highlighted, even though they have been mentioned only once by nurses, : knowing the Brazilian code, as well as medical and nursing ethics (rights of clients/patients); notions of epidemiology of diseases and death causes; use of non-invasive monitor, defibrillator and pacemaker; knowing emergency equipment and risks of extrication devices; knowing about communication and interpersonal relation as a health care strategy, access to intermediate airway and telemedicine to use medication in emergency situations in the absence of medical professionals.

At SAMU 192, intermediate care support units are predicted, and the team is made by one nurse, one nurse assistant and one driver: some ambulances have basic support material and other have advanced support material. These nurses receive specific training to work in this kind of care. In this context, the use of telemedicine plays an important role, just like the establishment of care protocols, to enable efficiency and quality of care ${ }^{(6-7)}$.

Regarding the technical skills suggested by nurses, in addition to those provided in the Regulation, we have observed that preparing and administering medications, including the technique of peripheral, intraosseous and femoral venous access, managing and dosing drugs, was considered a basic skill by ten out of 23 nurses. To acquire these skills, nurses must perform practical activities.

Once again, issues "recognizing cardiac rhythm" and "knowing and interpreting ECG and use of transcutaneous pacemaker" have been suggested, both as basic skill and as complementary by nurses.
Knowing the techniques of some invasive procedures, such as, orotracheal and nasotracheal intubation, needle decompression, chest drainage, phlebotomy, cricoid puncture, and use of transcutaneous pacemaker were considered as complementary by nurses; however these techniques are exclusively performed by physicians.

Since the work of nurses must follow their clinical practice in PHC, data from PHC charts were also collected, to characterize practice based on the types of occurrence and procedures conducted in addition to their opinion.

Data from 1,359 charts of pre-hospital care were randomly collected, from two services SAMU $192 / 193,892$ (65.6\%) from SAMU 192, and 467 (34.4\%) from SAMU 193.

Of the total of chart, $860(65.0 \%)$ were related with care of male patients, and 400 (29.4\%) were between 15 and 29 years old, 284 (20.9\%) between 30 and 44 years old, and 200 (14.7\%) between 45 and 59 . It should be pointed out that $24.8 \%$ of people seen were over 60 . Care of children from 0 to 14 was less frequent $(5.7 \%)$.

These data show the need for theoretical knowledge and skills in nurse's education, in all ages, due to the specificity of each life cycle, however, with greater emphasis in young adults.

Considering that care charts present records of different events, 777 records were for clinical events and 764 were trauma events.

Among clinical events, the most frequent were heart events, totaling 205 (26.4\%), followed by neurological and respiratory, with 184 (23.7\%) and $112(14.4 \%)$, respectively.

In the group of trauma events, we could observe car accidents and falls as the most frequent events, 218 for cars (28\%), and 213 for falls (27.9\%). Of the 58 events of interpersonal violence (7.6\%), 28 referred to aggression $(3.7 \%), 20$ to gun shots $(2.6 \%)$, and 10 to perforating objects $(1.3 \%)$.

The education of these professionals should have a global view on care in the programmatic content of the courses.

From the data collected we could observe incidence of different types of injury in the 764 trauma events, with 981 injury recorded. Blunt soft tissue injury and bruises were more frequent, totaling $624(63.6 \%)$, followed by extremity trauma, with $127(12.9 \%)$, and traumatic brain injury with $93(9.5 \%)$. 
Cardiorespiratory arrest (CRA) was more common among patients with clinical diseases 158 $(11.6 \%)$ than in patients with some kind of trauma $23(1.7 \%)$. The number of CRA seen in this type of care shows that nurses must learn, in their education, in addition to scientific knowledge, promptness, and technical skills to work with severe patients in stressful situations. To that end, they must go through similar situations several times.

The number of procedures performed at APH in the 1,359 patients totaled 4,550. The five most commonly performed procedures were: oxygen therapy, (705 - $15.5 \%$ ) followed by heart monitoring (597 - 13.1\%), placing rigid spinal board (548 $12.0 \%)$, administering medication (503 - 11.0\%) and peripheral venous access (502 - 11.0\%). Sixty-seven maneuvers of cardiac resuscitation were performed $(1.47 \%)$.

Analysis comparing the opinion of nurses and their clinical practice through PHC charts was performed observing knowledge and skills considered as basic by most, and the most frequently observed events and procedures.

Nurses taking part in this study considered as basic or necessary for clinical practice in PHC almost all issues (91.30\%) presented in Regulation \# 2,048.

Basic life support and management of equipment for circulatory emergency were pointed out as basic knowledge for $84.0 \%$ of nurses. Additionally, they mentioned the need for theoretical knowledge on the maneuvers and resources used in cardiopulmonary resuscitation (CPR), ability to identify cardiac rhythm and preparation and ministration of medication. We may relate this data with the number of CPR and the importance of knowledge and $C P R$ training. The record on the occurrence of CPR in the care charts showed that, of the total of 1359 patient, 181 (13.31\%) had a record of cardiac arrest, of which, 67 (37.01\%) received PCR maneuvers. This is therefore a necessary part of the course, since nurses are responsible for basic and advanced support in a situation of extreme severity which could define patients' survival. The need for constant training for updates in theory and practice of nurses in the performance of PCR is highlighted following the guidelines of the American Heart Association, which assesses and spread, periodically, evidences giving basis to the changes related to CPR maneuver and the use of defibrillation in all kinds of patient ${ }^{(8)}$.
Among the basic theoretical content and skills, control measures for controlling severe respiratory dysfunction in children and adults is highlighted as basic by $80 \%$ of nurses, together with basic life support and management of basic and advanced ventilation equipment. Although clinical and respiratory events have been the third more frequent $(14.4 \%)$, the need for oxygen therapy is frequent in most events either clinical or trauma. Among the procedure performed during $\mathrm{PHC}$, it was seen that oxygen therapy was the most frequently recorded procedure $(15.50 \%)$.

Regarding care of children and adolescents, although the frequency of care at PHC was low (5.7\%), there was concern from nurses to acquire theoretical knowledge and skills in this specific area, due to the anatomical and physiological differences of this population. Thus, issues related to actions to control severe respiratory dysfunction in adults and children must be part of capacity building programs of professionals working at PHC.

Eighty per cent of the nurses also considered as basic theoretical contents and skills regarding trauma emergencies of adult patients, pregnant women, elderly and children.

Issue such as cinematics of trauma, technique for difficult vein access, maneuver of equipment, and respiratory dysfunction at trauma, suggested by most nurses as basic skills; corroborate the need for capacity building of nurses to assist in trauma, since the number of trauma events is high.

It is clear that skills must be extensively exhausted, during their education, enabling nurses to work in emergency situations that require promptness and ability. The most suitable way considered to teach the content of nursing processes is having the same professor approaching theory and practice, enabling interconnecting the issue, which was introduced in the theory and applied to the practice ${ }^{(9)}$.

Another issue pointed out by $80 \%$ of nurses as basic theory and skill for PHC was related to the care of pregnant women in normal labor, dystocia, and obstetric complications. Although it was considered as a basic content, in clinical practice, this type of event was not frequent (6.2\%). However, as they are specific knowledge and skills, nurses working at PHC must be skilled to aid pregnant women and newly born.

Although knowledge and skills of Regulation \# 2,048 assessed, were those considered basic for 
over $80 \%$ of nurses, it was observed that, generally speaking, suggestions presented by them are implied in the other items of the Regulation.

Being aware of the need for developing specific and differentiated competences reinforces the importance of planning capacity building and specialization programs for nurses working at PHC. To that end, epidemiological data of the region were observed. Additionally, teaching and pedagogical methods that enabled developing clinical thinking for quick decision making in emergency situations are necessary, together with valuing the development of skills to perform procedures quickly and fast ${ }^{(10)}$.

"Fixed contents not linked with practice must be abandoned to integrate in the new teaching process, where knowledge is shared and related"(11).

\section{CONCLUSIONS}

Results of the present study enable to conclude that theoretical contents and skills proposed by Regulation 2,048 are basic issue for capacity building of nurses working at PHC.

Analysis of the opinions of nurses on the need for theoretical knowledge and technical skills, according to their practice in PHC, demonstrated that issues pointed out by nurses as basic did not refer to the most frequent occurrences or procedures. These were related to situations that demanded decision making, promptness, and skill in periods of high stress or care for a specific population reinforcing the need for programs directed to the development of skills in this area.

\section{REFERENCES}

1. Holleran RS. Role of nursing in préhospital care. In: Prehospital Nursing: a collaborative approach. Sant Louis (USA): Mosby; 1994. p.3-21.

2. SAMU de France [homepage on the Internet]. France: Paramedical personal. [updated 2004 May 3; cited 2004 May 3]. Available from: http://www.saude.gov.br/samu 3. Conselho Regional de Enfermagem (São Paulo). Assistência de enfermagem pré-hospitalar. Revista 2005 maio-junho; 14-15. 4. Ferreira CSW. Os Serviços de Assistência às Urgências no Município de São Paulo: implantação de um sistema de atendimento pré-hospitalar [dissertação]. São Paulo (SP): Faculdade de Medicina/USP; 1999.

5. Ministério da Saúde (BR). Portaria no 2048/GM de 05 de novembro de 2002: Regulamento técnico dos sistemas estaduais de urgência e emergência. Brasília(DF); 2002.

6. Martin SE, Ochsner MG, Jarman RH. The LMA: A viable alternative for securing the ariway. Air Medical 1999 AprilJune; 18(2):89-92.

7. Timerman S, Ramires JAF, Barbosa JLV, Hargreaves LHH. Suporte básico e avançado de vida em emergência. Brasília (DF): Câmara dos Deputados, Coordenação de Publicações; 2000.

8. American Heart Association. 2005 American Heart Association Guidelines for Cardiopulmonary Resuscitation and Emergency Cardiovascular Care. Circulation 2005 November; 112 (Suppl I):6-57.

9. Dell' Acqua MCQ, Miyadahira AMK. Ensino do processo de enfermagem nas escolas de graduação em enfermagem do Estado de São Paulo. Rev, Latino-am Enfermagem 2002 março-abril; 9(1):1-15.

10. Deslandes SF. Frágeis Deuses: profissionais da emergência entre os danos da violência e a recriação da vida. Rio de Janeiro (RJ): Fiocruz; 2002.

11. Marin MJS. O ensino interdisciplinar e problematização: um recorte do conhecimento. Rev Nursing 2004 julho; 74(7):28-32. 